\title{
Corrigendum: Offshore pile load tests in Challk to support the design of jacket foundations
}

Magnus Geduhn Dr-Ing

Senior Project Manager, Geotechnical Engineering, Ramboll, Hamburg, Germany (corresponding author: magnus.geduhn@ramboll.com)

\section{Pedro Barbosa MSc}

Senior Geotechnical Engineer, Iberdrola, London, UK

Jan Dührkop Dr-Ing

Chief Consultant, Geotechnical Engineering, Ramboll, Hamburg, Germany

\section{Anders H. Augustesen PhD}

Lead Geotechnical Specialist, Geotechnical Site Assessment,

Ørsted, Fredericia, Denmark; formerly Geotechnical Chief Specialist,

Marine \& Foundation Engineering, COWI, Aalborg, Denmark
Martin U. Østergaard MSc

Geotechnical Specialist, Marine \& Foundation Engineering, COWI, Aalborg, Denmark

\section{Jørgen S. Steenfelt PhD}

Technical Director, Marine \& Foundation Engineering, COWI, Kongens Lyngby, Denmark
The authors regret that following ahead of print publication of the article by Geduhn et al. (2018) on 28 August 2018, it was identified that three names - Anders H. Augustesen, Martin U. Østergaard and Jørgen S. Steenfelt - were omitted from the list of authors. Their affiliation details are provided in the author list of this correction.

The authors also wish to add four references and their citations to the article, as detailed below.

(i) Dührkop et al. (2014) should be cited in section 3 ('Geotechnical properties of Chalk').

(ii) Augustesen et al. (2015) and Dührkop et al. (2015) should be cited in section $3 \cdot 2$ ('Strength properties'), in the paragraph preceding Equation 1.

(iii) Augustesen et al. (2015) should be cited in section 3.2 ('Strength properties'), in the second paragraph below Figure 3.

(iv) Geduhn et al. (2017) should be cited in the caption of Figure 6.

(v) Augustesen et al. (2015) and Dührkop et al. (2014, 2015) should be cited in section 6 ('Basic and detailed pile design: axial resistance'), in the fourth paragraph below Equation 5.

(vi) Augustesen et al. (2015) should be cited in the caption of Figure 11.

\section{REFERENCES}

Augustesen AH, Leth CT, Østergaard MU et al. (2015)

Design methodology for cyclically and axially loaded piles in chalk for Wikinger OWF. In Frontiers in Offshore Geotechnics III: Proceedings of the Third International Symposium on Frontiers in Offshore Geotechnics (ISFOG 2015), Oslo, Norway, 10-12 June 2015 (Meyer V (ed.)). CRC Press, Boca Raton, FL, USA, vol. 2, pp. 509-514.

Dührkop J, Geduhn M, Augustesen AH, Østergaard MU and Barbosa P (2014) Kreide und Kreidestein als baugrund für offshorewindenergieanlagen in der Ostsee. In 33rd Baugrundtagung mit Fachausstellung Geotechnik, Berlin, Germany, 20-22 September 2014.

Dührkop J, Augustesen AH and Barbosa P (2015) Cyclic pile load tests combined with laboratory results to design offshore wind turbine foundations in Chalk. In Frontiers in Offshore Geotechnics III: Proceedings of the Third International Symposium on Frontiers in Offshore Geotechnics (ISFOG 2015), Oslo, Norway, 10-12 June 2015 (Meyer V (ed.)). CRC Press, Boca Raton, FL, USA, vol. 2, pp. 533-538.

Geduhn M, Barbosa P, Dührkop J et al. (2018) Offshore pile load tests in Chalk to support the design of jacket foundations. Proceedings of the Institution of Civil Engineers - Geotechnical Engineering 171(6): 508-517, https://doi.org/10.1680/ jgeen.17.00217.

Geduhn M, Barbosa P, Steenfelt JS and Augustesen AH (2017) Statische und dynamische probebelastungen an stahlrohrpfählen in $40 \mathrm{~m}$ wassertiefe in der Ostsee. Bautechnik 94(12): 842-850 (in German). 